\title{
The Influence of Corporate Social Responsibility Disclosure, Profitability and Leverage on Informative Profit with Environmental Performance as Moderating Variables
}

\author{
$1^{\text {st }}$ Dedi Putra ${ }^{1}, 2^{\text {nd }}$ Rhiska Gustiana ${ }^{2}$ \\ \{dedi.putra@darmajaya.ac.id ${ }^{1}$,rhiskag8@gmail.com ${ }^{2}$ \} \\ Faculty of Business and Economics, Institute of Information \& Business Darmajaya Jl. Z.A. Pagar Alam \\ No. 93, Gedong Meneng, Bandar Lampung 35142 - INDONESIA Telp. (0721)787214 Fax. (0721) \\ $700261^{1,2}$
}

\begin{abstract}
The objective of this research was proving empirically the effect of the corporate social responsibility, the profitability, and the leverage on the earnings response through the environmental performance as a moderating variable. The population of this research was the manufacturing companies indexed in Indonesia Stock Exchange and Corporate Performance Rating Program in 2014-2016. The sampling technique used in his research was the purposive sampling. A number of samples used in this research were 21 companies. The time of this research was 2014-2016 so that there were 63 observed data. The data analysis technique used in this research was the multiple linear regression. The analytical tool used in this research was SPSS V.20. The result of this research showed that the corporate social responsibility, the profitability, and the leverage had a significant effect on the earnings response.
\end{abstract}

Keywords: Corporate Social Responsibility, Profitability, Leverage, Earnings Response Coefficient (ERC).

\section{Introduction}

One of the information in financial statements that investors respond to and influence economic decision making is information about profits (Boediono, 2005). Profits are generally seen as a basis for taxation, determinants of dividend payment policies, investment guidelines, decision making, and predictive elements. According to Roy Chow Dhury and Sletten (2012) refer to informative earnings as informational profit defined as the ability of earnings in the current period that can help investors determine the rate of return or return in the future.

Research by Ball and Brown (1968) found a significant relationship between company earnings announcements and changes in stock prices. When a company announces an increase in profits, there will be a positive tendency to change in stock prices and vice versa if profits decline, there will be a negative change in stock prices. Some researchers have found a coefficient used to measure the strength of information earnings in influencing stock returns earnings) which is measured by the earnings response coefficient or commonly called Earnings Response Coefficient (ERC which is the correlation between unexpected earnings and abnormal stock returns). ERC is the coefficient used to measure the amount of stock 
returns in response to profits reported by the company. Every company has a different variation of relationship between company profits and shares According to Scott (2009).

The phenomenon that occurs is at PT Japfa Comfeed Indonesia Tbk. PT Japfa Comfeed Indonesia Tbk (JPFA) recorded a drastic decline in net income in 2017. Japfa's net profit fell by Rp1.06 trillion or approximately $51.69 \%$. Launching information disclosure issued by the company on the Indonesia Stock Exchange (IDX) website on Friday (02/03/2018), net profit attributable to owners of the parent entity was recorded at Rp997.35 billion in 2017. The net profit in the same period in the previous year, reaching Rp2.06 trillion. In fact, the company's sales have increased to IDR 29.6 trillion from IDR 27.06 trillion. As a result, earnings per share of Rp88 from the previous Rp. 189. On the other hand, the company's debt also increased to Rp. 11.29 trillion from Rp. 9.87 trillion. The debt consists of short-term debt of Rp. 4.76 trillion and long-term debt of Rp. 6.52 trillion. (Jakarta, economy.okezone.com).

An information is said to be informative if the information can change investors' beliefs in making investment decisions. The existence of new information in addition to financial statements will increase trust among investors towards a company. Currently information that gets a lot of spotlight is about corporate social responsibility. Corporate social responsibility or corporate social responsibility is used as the availability of financial and non-financial information relating to organizational interactions with the physical environment and social environment that can be made in the company's annual report or separate social report (Guthrie and Athews 1985 in Rakhiemah and Agustia, 2009).

According to Suratno et al. (2006) environmental performance or environmental performance is the company's performance in creating a green environment. Patten (2002) revealed that "environmental performance is quantified as the company 's specific amount of toxicity released into the environment". It can be interpreted that environmental performance is a company's performance as measured by the extent to which poisons released by the company into the environment. In Indonesia, the company's environmental performance is assessed by the Ministry of Environment through a company performance rating assessment program in environmental management (PROPER) using colors ranging from the best, namely gold, green, blue, red to the worst black (http: //www.menhl. go.id). Through this program, companies are expected to increase compliance in management and environmental management, because the results of this ranking will be announced to the public, so that it can have an impact on the reputation of the company. Through this also the community will find it easier to know the level of management arrangements for the company (Rakhiemah and Agustia, 2009). The research conducted by Pranbadari and Suryanawa (2014) states that the higher the environmental performance will affect the reaction of investors, for investors in making investment decisions in order to use PROPER as one of the information to consider in investment investment.

This study refers to previous research conducted by Herawaty and Wijaya (2016) with the title "The Effect of Corporate Social Responsibility Disclosure, Profitability, and Leverage on Informative Profit with Environmental Performance as Moderating Variables". By changing the measurement of Profitability from ROA to ROE and the observation period from 20102014 to 2014-2016. The object of research is a publicly listed manufacturing sector company listed on the Indonesia Stock Exchange and consistently participating in the PROPER program for 2014-2016. 


\section{Research Hypothesis}

\subsection{The Influence of Corporate Social Responsibility Disclosures on Formality of Profit}

Hidayati and Murni's research (2009) found that disclosing corporate social responsibility can reduce an investor's reaction to earnings announcements, which can be measured by earnings response coefficient. This can be caused by the existence of other information besides the profit that can be used by investors in making investment decisions.

H1. Disclosure of corporate social responsibility has an effect on earnings informativeness.

\subsection{Effect of Profitability on Formality of Profit}

Profitability ratios can measure the effectiveness of company performance and show the company's ability to generate profits or profits for a period. If this profitability is associated with earnings response coefficient or profit response coefficient, then it can be seen if the company with high profitability, then the profits generated by the company will increase, and affect large earnings response coefficients to help investors invest compared to companies with profitability low. The results of research from Kusuma Herawati and Wijaya (2016) show that profitability has a positive effect on earnings response coefficient.

\section{H2. Profitability has an effect on profit informativeness.}

\subsection{Effect of Leverage on Informative Profit}

Companies that have a high degree of leverage mean that they have a debt greater than capital, which means that the financial burden is heavier and the risks faced by the company are higher. That means, companies with high leverage will cause low earnings response coefficients. The results of research from Murwaningsari (2008) and Wulansari (2013) prove that leverage negatively influences earnings response coefficient.

\section{H3. Leverage influences informativeness of earnings.}

2.4 The Influence of Environmental Performance which Moderates the Relationship between Corporate Social Responsibility Disclosures Against Informative Profit

Research conducted by Rakhiemah and Agustia (2009) shows that environmental performance has an effect on disclosure of corporate social responsibility, that companies with good environmental performance will tend to express company performance, because it provides good news for market participants. Therefore, companies with good environmental performance disclose information on the quantity and quality of the environment which is more compared to companies with worse environmental performance. The better the environmental performance of the company in improving its environment, the higher the value of the company, so that investors will respond to the company.

H4. Environmental performance influences the relationship of disclosure of corporate social responsibility to informational profit.

2.5 The Influence of Environmental Performance which Moderates the Relationship of Profitability to Informative Profit

The benefits that will be obtained by the company, because it performs environmental performance, namely the company's reputation in the eyes of the community becomes good so that it can improve the company's financial performance which directly contributes to 
increasing the profitability of the company. According to Fitriani et al. (2015) that the company's environmental performance increases, this will increase the level of trust of stakeholders, especially investors, thus the return on assets of the company increases and will get a good response from investors to invest in the company.

\section{H5. Environmental performance affects the relationship of profitability to profit informativeness.}

\subsection{The Influence of Environmental Performance which Moderates Leverage Relationships to Informative Profit}

Companies that have a high debtto equity ratio will be responded negatively by investors, because the company's debt is greater than the company's capital. But this will decrease, if the company has good environmental performance, and will be responded positively by investors. Profit is believed to be the main information presented in the company's financial statements (Lev, 1989, in Sayekti and Wondabio, 2007). Research conducted by Pranbandari and Suryanawa (2014) that the higher the environmental performance affects the reaction of investors, and for investors to make investment decisions to use PROPER as one of the information to consider in investing investment.

H6. Environmental performance influences the relationship of leverage to profit informativeness.

\section{Research Methods}

\subsection{Sample and Population}

According to Arikunto (2010: 173) the population is the whole of the research subjects. The population in this study are manufacturing companies listed on the Indonesia Stock Exchange and consistently follow PROPER in 2014-2016. According to Arikunto (2010: 174), the sample is partially or representative population studied. Samples were selected using purposive sampling method. The criteria for the sample to be used are:

1. Manufacturing sector companies listed on the Indonesia Stock Exchange (IDX) for the 2014-2016 period.

2. Manufacturing sector companies that publish a full annual report on the Indonesia Stock Exchange (IDX) website during the 2014-2016 period.

3. Manufacturing sector companies listed on the Indonesia Stock Exchange (IDX) that use the rupiah currency in their 2014-2016 financial statements.

4. Manufacturing sector companies that consistently follow the Corporate Performance Rating Program in Environmental Management for three consecutive years (2014-2016).

5. Manufacturing sector companies that consistently follow the Corporate Performance Rating Program in Environmental Management, which report corporate social responsibility in the company's annual report.

6. Manufacturing sector companies that have complete stock price data and there are no consistent stock prices during 2014-2016.

\subsection{Operational Definition of Variables}

1. Corporate Social Responsibility 
Corporate social responsibility can be interpreted as an industry commitment to account for the impact of operations in the social, economic and environmental dimensions and to maintain that these impacts contribute to the community and the environment described in the formula:

$\mathrm{CSRDI}_{\mathrm{j}}=$

\section{Profitability}

The measurement of profitability in this study uses Return On Equity (ROE), which is the amount of returns from net income to equity and expressed as percent. This is used to measure the ability of an issuer to generate profits by capitalizing on the equity that has been invested by the shareholders.

Profitability is proxied using Return On Equity (ROE).

$\mathrm{ROE}=$

\section{Leverage}

Companies with high leverage mean that they have more debt than capital, so if there is an increase in profits, the beneficiaries are debtholders (Sri and Nur, 2007). Leverage/Capital Structure is proxied using Det To Equity Ratio (DER).

$\mathrm{DER}=$

4. Environmental Performance

According to Suratno, et al (2006) environmental performance is the company's performance in creating a good environment.

Table 1. PROPER Rating

\begin{tabular}{|c|l|l|}
\hline Scale & Meaning & Color \\
\hline 1 & Worst & Black \\
\hline 2 & Bad & Red \\
\hline 3 & Good & Blue \\
\hline 4 & Better & Green \\
\hline 5 & The Best & Gold \\
\hline
\end{tabular}

5. The opportunity to grow

Sumber : Kementrian Lingkungan Hidup, 2013

Price to Book Value (PBV) is used to proxy for growth opportunities (growth opportunities). Price to book value is a ratio that shows whether the company's current market price is above or below the company's book value. The higher this ratio means the market believes in the prospect of the company.

$\mathrm{PBV}=$

6. Informative Profit

One measurement that can be used to measure shareholders' reaction to the informativeness of accounting earnings is earnings response coefficient. Definition of earnings response coefficients according to (Scott, 2003). Imaging Response Coefficient (ERC) is a 
measure of size abnormal return of a stock in response to an abnormal earnings component (unexpected earnings) reported by the company that issued the stock.

Tahap Pertama menghitung CAR (Cummulative Abnormal Return)

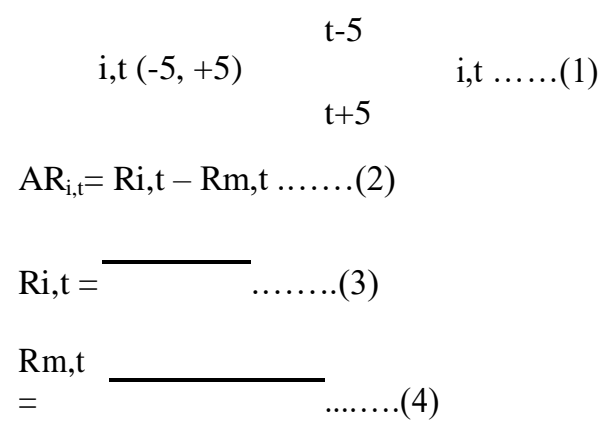

The second stage, calculate EU (Unexpected c Earnings) or surprise profit

$\mathrm{UE}_{\mathrm{i}, \mathrm{t}}=$

Then, Regress Cummulative Abnormal Return (CAR) and Unexpected Earnings (EU) then the earnings response coefficient is formulated as follows (Chaney and Jeter, 1991):

$\mathrm{CAR}_{\mathrm{i}, \mathrm{t}(-5,+5)}=\square_{\mathrm{O}}^{+} \square_{1} \mathrm{UE}_{\mathrm{i}, \mathrm{t}}+\mathrm{s}_{\mathrm{i}, \mathrm{t}}$

\subsection{Data Analysis Technique}

\section{Analysis of this research data includes:}

1) Descriptive Statistics

2) Regression Test: Normality Test, Multicollinearity Test, Autocorrelation Test and Heterocapacity Test.

3) Multiple linear regression, with the Equations of multiple linear regression models used as follows:

$\mathrm{CAR} \beta 0+\beta 1 \mathrm{~S} \mathrm{I}+\beta 2 \mathrm{OE}+\beta 3 \mathrm{DE}+\beta 4 \mathrm{~S} \mathrm{I} * \mathrm{P} \quad \mathrm{OPE}+\beta 5 \mathrm{OE} * \mathrm{P} \quad \mathrm{OPE}+\beta 6 \mathrm{DE} * \mathrm{P} \mathrm{OPE}$ $+\beta 7 \mathrm{PBV}+€$

4) Test of Determination Coefficient, f Test, and Hypothesis Test

\section{Results And Discussion}

\section{Classic assumption test}

\section{Normality Test Results}

The results of the normality test using the Kolmogrov-Smirnov One-Sample Test show a significant value (2_tailed) of $0,000<0,05$, which means that the residual data is not normally distributed. Therefore a corrective action is taken, namely using outlier observations of data. The limitation of the normal curve is to have a Z-Score value with a range of -2.5 to 2.5 (Sufren and Natanael, 2013: 15). The results after the outliers are that the significant level (2-tailed) is $0.025<0.05$, which means that the data is still not normally distributed. 
According to Gujarati (2011) that it can ignore the nomination test because data is biased with various methods available.

\section{Multicollinearity Test Results}

In general, the moderating regression analysis model will cause high multicollinearity between variables, the existence of multicollinearity problems is difficult to avoid because of the moderating variable which is the interaction of independent variables. towards the dependent variable (Gujarati, 2009).

\section{Autocorrelation Test Results}

It can be seen that the Dw value obtained is 1.944, then the value of the watson durbin will be obtained, namely $\mathrm{dl}$ at 1.5052 and the value (du) of 1.6475. Because the Dw value is < $4-\mathrm{du}$ where $1,944<2,3525$, it can be concluded that there is no autocorrelation in the regression model.

\section{Heteroscedaticity test}

Based on the picture above shows the picture of heteroscedasticity test results, from the scatterplot graph image above shows that the points do not form a specific pattern and spread on the $\mathrm{Y}$ axis. So, it can be concluded that the regression model in this study did not have heteroscedasticity.

\section{Determination Test R2}

In the summary model shows that the adjusted R square or coefficient of determination is 0.383 or $38.3 \%$ which means five variables of Corporate Social Responsibility, Profitability, Leverage with moderating variables namely Environmental Performance and control variables namely Growth Opportunity can explain the dependent variable Informative Profit of $38.3 \%$ and the remaining $61.7 \%$ is explained by other reasons.

\section{F Test/Feasibility Model}

From the results above obtained significant coefficient results indicate that a significant value of 0,000 is less than $0.05(\alpha 5 \%)$ with a calculated $F$ value of 6.050 and $F$ table 3.16 . This means that sig $<0.05$ and Fcount $>$ F table, it was decided to reject Ho and accept H1. Thus it can be concluded that the resulting regression model is suitable to see the effect of Corporate Social Responsibility Disclosure, Profitability and Leverage on the Informativeness of Profit with Environmental Performance As a Moderating Variable in manufacturing companies on the Indonesia Stock Exchange.

\section{Hypothesis and Discussion Results}

\section{The Influence of Environmental Performance which Moderates the Relationship between Corporate Social Responsibility Disclosure and Informative Profit}

Based on the test results it is known that the coefficient value of Environmental Performance Moderating Corporate Social Responsibility Disclosure Relationship to Profit Informativeness is $0,000<0,05$. That explains that Environmental Performance Moderating Corporate Social Responsibility Disclosure Relationship and Informativeness Profit has a significant effect and the direction of regression coefficient shows that Environmental 
performance variables strengthen the relationship of corporate social responsibility disclosures to profit informativeness. The results of this study indicate that environmental performance has an effect on disclosure of corporate social responsibility, companies with good environmental performance will tend to reveal company performance, because it provides good news for market participants. Companies with good environmental performance, not only cover the company's concern for the environment, but also about product quality, product safety, corporate social responsibility towards the surrounding community, to the company's concern for safety and welfare of its work (Rakhiemah and Agustia, 2009), investors are more interested in investing their capital in companies that are environmentally friendly.

Effect of Environmental Performance that Moderates Profitability and Informative Profit

Based on the test results it is known that the coefficient value of Environmental Performance that Moderates the Relationship between Profitability and Informative Profit is $0,000<0.05$. This explains that Environmental Performance that Moderates the Relationship of Profitability and Informativeness Profit has a significant effect and the direction of the regression coefficient which has a positive direction shows that the variable environmental performance weakens the relationship of the effect of Profitability on informational informativeness. That the company's environmental performance increases, it will also increase the level of trust of stakeholders, especially investors, thus the value of the company's return on equity will increase and will get a good response from investors. The results of this study are in line with the research conducted by Fitriani et al (2005) which states a significant effect on Environmental Performance which moderates the relationship of Profitability to Informative Profit.

Effect of Environmental Performance that Moderates the Relationship of Leverage and Informative Profit

Based on the test results it is known that the coefficient value of Environmental Performance which Moderates the Relationship of Leverage and Informative Profit is $0.005<$ 0.05. This explains that environmental performance that moderates the relationship of leverage and profit informativeness has a significant effect and the direction of the regression coefficient that has a negative direction shows that environmental performance variables reinforce the relationship of influence to the informativeness of earnings. The higher the leverage, the better the performance of the company. But this will decrease, if the company has good environmental performance, and will be responded positively by investors. The results of this study are in line with the research of Herawaty and Wijaya (2015) which states a significant effect on Environmental Performance which moderates the relationship of Leverage to Informative Profit.

\section{The Effect of Growing Opportunities on Formality of Profit}

Based on the test results it is known that the coefficient value of the Growth Opportunity Against Informative Profit is $0.986>0.05$. This explains that Growth Opportunities have no significant effect on earnings informativeness. The possibility of growth is not statistically significant, this can happen because investors' motivation in their investment is not to get long-term profits but to get capital gains. Capital gain is an advantage that an investor gets from the difference in selling price minus the purchase price of a stock. This research is in line with research conducted by Margaretta (2006) which states that growth opportunities do not have a significant effect on earnings informativeness. 


\section{Conclusion and Suggestion}

\section{Conclusion}

Based on the results of the analysis that has been done, it can be concluded:

1. Disclosure of Corporate Social Responsibility affects the Informativeness of Profit, Profitability has an effect on Informativeness Profit and Leverage has an effect on the Informativeness of Profit

2. Environmental performance strengthens the relationship between Corporate Social Disclosure of responsibility for informational profit

3. Environmental performance weakens the profitability relationship with earnings informativeness

4. Environmental performance strengthens the relationship of leverage to profit informativeness.

\section{Suggestion}

Suggestions that can be given for further research to be even better, are as follows:

1. In further research, it is better to expand the population and sample and should add other independent variables that can affect earnings informativeness such as company size, it is expected that the adjusted $\mathrm{R}$ Square obtained will be greater, because the independent variable in this study can only explain earnings response coefficient variables amounting to $38.3 \%$.

2. In the next study, it is better to replace moderating variables such as auditor quality, because the results of this study are moderating variables that are environmental performance weaken and cannot strengthen the influence of independent variables on earnings informativeness and add control variables such as earnings and beta persistence or risk, because in this study using one control variable, namely the opportunity to grow.

\section{References}

[1]. Adisusilo, Pramudito. 2011. Pengaruh Pengungkapan Informasi Corporate Social Responsibility (CSR) Dalam Laporan Tahunan Terhadap Earning Response Coefficients (ERC). E-Jurnal. Semarang : Universitas Diponogoro Semarang.

[2]. Beaver, W., R. Lambert, dan S. Ryan. 1987. The Information Content of Security Prices. A Second Look. Journal of Accounting And Economics. Vol. 9, pp. 139-158.

[3]. Cho, J.Y., dan Jung, K. 1991. Earnings Response Coefficient: A Synthesis of Theory and Empirical Evidence. Journal of Accounting Literature. Vol. 10, pp. 85-116.

[4]. Ghozali, Imam, 2001. Statistik Non Parametric.Semarang: Universitas Diponogoro.

[5]. Gujarti. 2011. Ekonomertika. Salemba Empat.

[6]. Herawaty, Vinola dan Wijaya. 2016. Pengaruh Pengungkapan Corporate Social Responsibility, Profitabilitas, dan Leverage Terhadap Keinformatifan Laba Dengan Kinerja Lingkungan Sebagai Variabel Moderasi. Simposium Nasional Akuntansi (SNA) XIX, Lampung.

[7]. Mahendra, I dan D.S. Wirama2. 2017. Pengaruh Profitabilitas, Struktur Modal, Dan Ukuran Perusahaan Pada Earnings Response Coefficien. E-Jurnal Akuntansi Universitas Udayana

[8]. Melati, Rosa Aprilia dan Kurnia. 2013. Pengaruh Pengungkapan Informasi CSR dan Profitabilitas Terhadap Earning Response Coefficient (ERC). Jurnal Ilmu \& Riset Akutansi Vol. 2 No. 12.

[9]. Rakhiemah, Aldilla Noor dan Dian Agustia. 2009. Pengaruh Kinerja Lingkungan Terhadap Corporate SocialResponsibility (CSR) Disclosure dan Kinerja Finansial Perusahaan Manufaktir yang Terdaftar di BursaEfek Indonesia. Simposium Nasional Akuntansi XII. Palembang. 
[10]. Sayekti, Y. dan L. S. Wondabio. 2007. Pengaruh CSR diclosure terhadap Earning Response Coefficient yang terdfatar di Bursa Efek Jakarta. Simposium Nasional Akuntansi X.

[11]. Scott, William. R. 2015. Financial Accounting Theory. Edition 7th. Canada: Prentice Hall Canada Inc.

[12]. Zahroh, N. dan U. Siddharta. 2006. " Pengaruh Ukuran Perusahaan, Pertumbuhan dan Profitabilitas Perusahaan terhadap Koefisien Respon Laba dan Koefisien Respon nilai Buku Ekuitas : Studi pada Perusahaan Manufaktur di Bursa Efek Jakarta”. Simposium Nasional Akuntansi 9. Padang.

[13]. https://economy.okezone.com/read/2018/03/02/278/1866922/laba-bersih-japfa-comfeed-turun-rp106-triliun-jadi-rp997-miliar

[14]. https://text-id.123dok.com/document/7qvrw0wry-laba-dan-keinformatifanlaba.htmlhttp://cantikef.blogspot.com/2016/05/teori-legitimasi.html

[15]. www.finance.yahoo.com

[16]. www.idx.co.id

[17]. www.menlh.go.id

[18]. www.sahamok.com 